Research paper

\title{
Spring water quality and discharge assessment in the Basantar watershed of Jammu Himalaya using geographic information system (GIS) and water quality Index(WQI)
}

\author{
Ajay Kumar Taloor ${ }^{\mathrm{a}, *}$, Rayees Ahmad Pir ${ }^{\mathrm{b}}$, Narsimha Adimalla ${ }^{\text {c, }}$, Sajid Ali ${ }^{\mathrm{e}}$, \\ Drinder Singh Manhas ${ }^{\mathrm{a}}$, Sagarika Roy ${ }^{\mathrm{f}}$, Anil Kumar Singh ${ }^{\mathrm{h}}$ \\ a Department of Remote Sensing and GIS, University of Jammu, Jammu, 180 006, India \\ ${ }^{\mathrm{b}}$ Central Ground Water Board (CGWB) North Western Himalayan Region, Jammu Govt. of India, Ministry of Water Resources RD \& GR, India \\ ${ }^{\mathrm{c}}$ School of Environmental Science and Engineering, Chang'an University, No. 126 Yanta Road, Xi'an 710054, Shaanxi, China \\ ${ }^{\mathrm{d}}$ Key Laboratory of Subsurface Hydrology and Ecological Effects in Arid Region of the Ministry of Education, Chang'an University, No. 126 Yanta Road, Xi'an 710054, \\ Shaanxi, China \\ ${ }^{\mathrm{e}}$ Birbal Sahni Institute of Palaeobotany Lucknow, India \\ ${ }^{\mathrm{f}}$ Earth and Environmental Science Undergraduate Program Indian Institute of Science, Bangalore, 560013, India \\ ${ }^{\mathrm{h}}$ Farm Guide Gurugram, Haryana 122018, India
}

\section{A R T I C L E I N F O}

\section{Keywords:}

Spring water quality

Spatial distribution

Spring discharge

Basantar watershed

India

\begin{abstract}
A B S T R A C T
The demand for fresh spring water recently increased due to intensive domestic, industrial irrigation practices which typically caused depletion of water resources and deterioration of water quality. The spring water quality was analyzed for its major hydrochemistry and hydrochemical evolution of the spring water in the study area. A total of 60 spring water samples were collected from the three kinds of terrain (mountainous, hilly and plain) and analyzed for $\mathrm{pH}$, electrical conductivity (EC), total dissolved solids (TDS), total hardness (TH), calcium (Ca ${ }^{2+}$ ), magnesium $\left(\mathrm{Mg}^{2+}\right)$, sodium $\left(\mathrm{Na}^{+}\right)$, potassium $\left(\mathrm{K}^{+}\right)$, bicarbonate $\left(\mathrm{HCO}_{3}^{-}\right)$, sulphate $\left(\mathrm{SO}_{4}^{2-}\right)$, chloride $\left(\mathrm{Cl}^{-}\right)$, nitrate $\left(\mathrm{NO}_{3}^{-}\right)$, and fluoride $\left(\mathrm{F}^{-}\right)$. The water quality of drinking purposes was plotted in the Piper trilinear diagram which reveals that spring hydrochemistry is dominated by the alkaline earth and weak acids. Gibbs diagram reveals that the spring water chemistry is primarily controlled by rock-water interaction in the investigated region. The water quality index (WQI), 45\% of samples fall in the excellent category, 50\% of spring samples fall in good categories for drinking purposes. The $\mathrm{pH}$ and TDS are within the permissible limit ranges from 7 to 8.4 and 123 to 793 respectively. Based on chemical analysis of the various parameters such as non-carbonate hardness, sodium percentage sodium absorption ratio, residual sodium carbonate were calculated to define the quality of spring water for irrigation purposes. The discharge of spring water was also calculated during the pre-monsoon season and found that $70 \%$ of samples have discharge more than $20 \mathrm{~L}$ per second (Lps).
\end{abstract}

\section{Introduction}

Water scarcity in many parts of the world has become an unpleasant reality. Groundwater seems to be the potential natural resources capable to reverse this situation. Uncovering the spatial patterns of groundwater occurrence. The water economy of India is under the huge pressure and safe drinking water supply to 1.5 billion people by the end of next decade is one of the major challenge for the country. Himalayas being endowed with rich river water system may not able to cater the demands of water for agriculture, domestic and industrial uses in the coming years due to unscientific and improper use of water which led to acute shortage of water supply in many parts of India. Due to unavailability or inadequate quality of surface water, demand for ground water resources has increased over the years for drinking purposes in the world, especially in densely populated area particularly in the Indian sub-continent where two-third of the total population use groundwater for drinking purposes (Barakat et al., 2018; Bhat et al., 2019; Chen et al., 2019; Jasrotia et al., 2019a).

Springs is the main source of water for the people in the Himalayas both urban and rural chunk of large population depends on spring as a

\footnotetext{
* Corresponding author.

E-mail address: ajaytaloor@gmail.com (A.K. Taloor).
} 

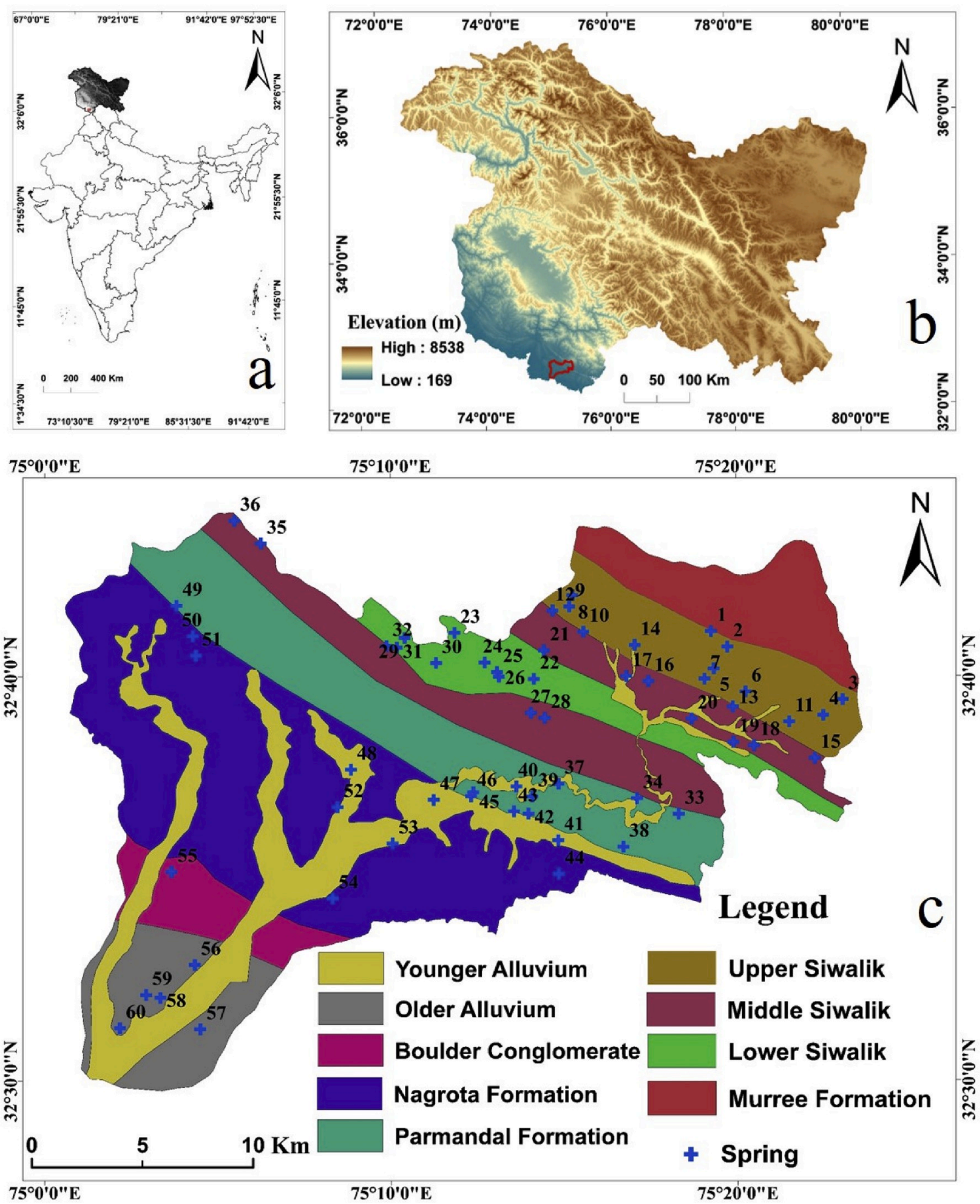

Fig. 1. (a) Location map of India, (b) location map of J\&K depicting the location of Basantar watershed, (c) Geology map depicting the location of springs.

source of fresh water for the drinking, domestic and agricultural purposes and mostly used without prior water treatment in Himalayan villages (Bartarya, 1991; Bartarya and Valdiya, 1989; Negi and Joshi, 2004; Jasrotia et al., 2011, 2018; Bartarya and Bahukhandi, 2012). Himalayas being considered as water tower of the Asia and endowed with adequate rainfall, most part of Himalaya regarded as dry land as far as agriculture is concerned (less than $2 \%$ of land is irrigated), and water stressed region in terms of accessibility of drinking water to people (Singh et al., 2017; Adimalla et al., 2020).

Spring generally is a point at which water flows from an aquifer to the surface of the earth occur where ground surface and the impermeable rocks intersect with the ground water table. The occurrence mostly depends on rocks recharge characteristics, such as, lithology, porosity and permeability of the topsoil, hydrogeomorpholgy slope of the surface and precipitation (Joshi, 2006; Ansari et al., 2015; Haque et al., 2020). Besides the occurrence the management of springs is also a biggest challenge in the hilly regions of Himalaya due to over drafting of the water by hand pumps and tube wells in the small aquifers and pollution form the anthropogenic activities. The eco-geological labyrinth of Himalaya is under the grip of various natural dynamism, anthropogenic interventions. Due to climate change and global warming, melting of glaciers, reduced snowfall, more frequent heavy rainfall and widespread flooding has affected the water resources of Himalayas, consequently springs are widely affected. It is quite evident from the different sources that springs are drying up or their discharge is reducing throughout the Himalayas as it is mainly depending on rainfall pattern in the recharge 
Table 1

Stratigraphic succession of the study area (after Ranga Rao et al., 1988).

\begin{tabular}{|c|c|c|c|c|}
\hline Group & Sub Group & Formation & Lithology & Age \\
\hline $\begin{array}{l}\text { Jammu Alluvium } \\
\qquad \sim \sim \sim \sim \sim \sim \sim \sim \sim\end{array}$ & $\sim \sim \sim \sim \sim \sim \sim$ & $\begin{array}{l}\text { Younger and Older Alluvium } \\
\sim \sim \text { Unconformity } \sim \sim\end{array}$ & $\begin{array}{l}\text { Fine to coarse grained sand, silt and clay, Fine to medium grained } \\
\text { micaceous sand, silt and clay Coarse sand (cobble, boulder) Silt and } \\
\text { clay in valley fill deposit }\end{array}$ & $\begin{array}{l}\text { Recent to Upper } \\
\text { Pleistocene } \\
\sim \sim \sim \sim \sim \sim \sim \sim \sim \sim \sim\end{array}$ \\
\hline \multirow[t]{3}{*}{ Siwalik Group } & Upper Siwalik & $\begin{array}{l}\text { Boulder Conglomerate } \\
\text { Nagrota Formation } \\
\text { Parmandal Formation }\end{array}$ & $\begin{array}{l}\text { Sand, silt and clay dominantly coarse- grained sandstone and pink } \\
\text { grey mudstone }\end{array}$ & $\begin{array}{l}\text { Pliocene to Middle } \\
\text { Pleistocene }\end{array}$ \\
\hline & Middle Siwalik & & $\begin{array}{l}\text { Medium to coarse-grained sandstones and subordinate grey brown } \\
\text { mudstone }\end{array}$ & Upper Miocene \\
\hline & Lower Siwalik & & Red mudstone and fine medium- grained grey, green sandstone & Middle Miocene \\
\hline- & - & -Thrust- & - & - \\
\hline Murree Group & Upper Murree & & $\begin{array}{l}\text { Monotonous grey sandstone and grey, brown to yellowish } \\
\text { subordinate, mudstone, siltstone and clay }\end{array}$ & Early Miocene \\
\hline
\end{tabular}

area and variation in the amount of rain water that is able to in-filtrate the ground. The Himalayan ecosystem is quite fragile and susceptible to several changes caused due to natural and man-made problems. It is quite understood that if crisis persists it will affect livelihoods of millions of people in the Himalayas and particularly in the mountain belts (NITI Aayog, 2017).

Various researchers around the world and around India have studied the detail hydrochemistry and spring water quality in various to evaluate the major ion chemistry, radon concentration in water, geochemical processes controlling water composition and suitability of water for domestic, and drinking purposes (Brindha, and Elango, 2011; Bozau et al., 2013; Fonollosa et al., 2016; Al-Khashman et al., 2017; Barakat et al., 2018; Nnorom et al., 2019; Chen et al., 2019; Adimalla et al., 2020). In the recent studies use of GIS technology for spring potential mapping has also been well documented in many studies around the world (Ozdemir, 2011; Pourtaghi and Pourghasemi, 2014; Guru et al., 2017; Jasik et al., 2017; Rahmati et al., 2018; Jasrotia et al., 2019b; Adimalla and Taloor, 2020). The Basantar watershed is part of the Jammu plains and hilly stretch of Siwaliks in J\&K, the scarcity of water is quite hilly nature of terrain and sloppy surface mostly rain-fed and lack of proper guidance and management has led to the dying of many springs.
In the current study region, $70 \%$ residents merely rely on the spring water for domestic uses, which increase the demand of monitoring of water quality and discharge of the spring. The major objective of the research is to understand the spring water quality through detail hydrochemistry in the study area, to determine the various classifications of water, for drinking and irrigation purposes.

\section{Description of study area}

The study area lies between latitude $32^{\circ} 30^{\prime}$ to $33^{\circ} 55^{\prime} \mathrm{N}$ and longitude $75^{\circ} 1^{\prime}$ to $75^{\circ} 23^{\prime} \mathrm{E}$ and covers a total area of $610 \mathrm{~km}^{2}$. The study region is mostly covering of hilly terrain of Jammu Himalaya. The hydrogeomorphology, lithology, and slope play a major role in the evolution of the various types of drainage pattern in the study area. Basantar is the major river flowing in the northeast to southwest direction in watershed with Rui and Devak are its tributaries joins at the plains of Jammu Himalayas. The study area falls in subtropical to moist temperate climate with temperature ranges from $2^{\circ}-20^{\circ} \mathrm{C}$ in winter and $30^{\circ}-47^{\circ} \mathrm{C}$ in summer and average annual precipitation in the study area is $1208 \mathrm{~mm}$ (Jasrotia and Kumar 2014a).

Geologically study area is a part of the Siwaliks and Muree Formation lies in the hilly range of Lesser Himalaya from Early Miocene to Upper

Table 2

Instrumental, titrimetric and calculation methods used for chemical analysis of spring.

\begin{tabular}{|c|c|c|c|c|c|}
\hline Parameters & Characteristics & Analytical method & Reagents & Unit & Reference \\
\hline \multirow[t]{4}{*}{ General } & $\mathrm{pH}$ & $\mathrm{pH} / \mathrm{EC} / \mathrm{TDS}$ meter & $\mathrm{pH} \mathrm{4,} 7$ and 9.2 & & $\begin{array}{l}\text { APHA } \\
(2012)\end{array}$ \\
\hline & $\begin{array}{l}\text { Electrical Conductivity } \\
\text { (EC) }\end{array}$ & $\mathrm{pH} / \mathrm{EC} / \mathrm{TDS}$ meter & Potassium chloride & $\begin{array}{l}\mu \mathrm{S} / \\
\mathrm{cm}\end{array}$ & $\begin{array}{l}\text { APHA } \\
(2012)\end{array}$ \\
\hline & $\begin{array}{l}\text { Total dissolved solids } \\
\text { (TDS) }\end{array}$ & Calculation & EC X (0.55-0.75) & $\mathrm{mg} / \mathrm{L}$ & $\begin{array}{l}\text { APHA } \\
(2012)\end{array}$ \\
\hline & $\begin{array}{l}\text { Total hardness (as } \\
\text { CaCO3) }\end{array}$ & EDTA titrimetric & $\begin{array}{l}\text { EDTA, ammonia buffer and Eriochrome Black-T (EBT) } \\
\text { indicator }\end{array}$ & $\mathrm{mg} / \mathrm{L}$ & $\begin{array}{l}\text { APHA } \\
(2012)\end{array}$ \\
\hline \multirow[t]{4}{*}{$\begin{array}{l}\text { Major } \\
\text { cations }\end{array}$} & Calcium $\left(\mathrm{asCa}^{2+}\right)$ & EDTA titrimetric & EDTA, sodium hydroxide and murexide & $\mathrm{mg} / \mathrm{L}$ & $\begin{array}{l}\text { APHA } \\
(2012)\end{array}$ \\
\hline & Magnesium $\left(\operatorname{asMg}^{2+}\right.$ ) & Calculation & $\begin{array}{l}\mathrm{MgH}=\mathrm{TH}-\mathrm{CaH} ; \mathrm{Mg}=\mathrm{MgH} \text { X } \\
\text { Eq.Wt of Mg X Normality ofEDTA }\end{array}$ & $\mathrm{mg} / \mathrm{L}$ & $\begin{array}{l}\text { APHA } \\
(2012)\end{array}$ \\
\hline & Sodium $\left(\operatorname{asNa}^{+}\right)$ & Flame photometric & Sodium chloride $(\mathrm{NaCl})$ and $\mathrm{KCl}$ & $\mathrm{mg} / \mathrm{L}$ & $\begin{array}{l}\text { APHA } \\
(2012)\end{array}$ \\
\hline & Potassium $\left(\right.$ asK $\left.^{+}\right)$ & Flame photometric & $\mathrm{NaCl}$ and $\mathrm{KCl}$ & $\mathrm{mg} / \mathrm{L}$ & $\begin{array}{l}\text { APHA } \\
(2012)\end{array}$ \\
\hline \multirow[t]{5}{*}{ Major anions } & Bicarbonates $\left(\mathrm{HCO}_{3}^{-}\right)$ & Titrimetric & $\begin{array}{l}\text { Hydrosulfuric acid (H2SO4), phenolphthalein and } \\
\text { methyl } \\
\text { orange }\end{array}$ & $\mathrm{mg} / \mathrm{L}$ & $\begin{array}{l}\text { APHA } \\
(2012)\end{array}$ \\
\hline & Chloride $\left(\mathrm{Cl}^{-}\right)$ & Titrimetric & Silver nitrate (AgNO3), potassiumchromate & $\mathrm{mg} / \mathrm{L}$ & $\begin{array}{l}\text { APHA } \\
(2012)\end{array}$ \\
\hline & Fluoride $\left(\mathrm{F}^{-}\right)$ & $\begin{array}{l}\text { Fluoride (F-) ISE (Ion selective electrode; } \\
\text { ThermoOrion) }\end{array}$ & TISAB III and NaF & $\mathrm{mg} / \mathrm{L}$ & $\begin{array}{l}\text { APHA } \\
(2012)\end{array}$ \\
\hline & Sulphate $\left(\mathrm{SO}_{4}^{2-}\right)$ & UV visible spectrophotometer & $\begin{array}{l}\mathrm{HCl} \text {, ethyl alcohol, } \mathrm{NaCl} \text {, barium chloride, sodium } \\
\text { sulphate }\end{array}$ & $\mathrm{mg} / \mathrm{L}$ & $\begin{array}{l}\text { APHA } \\
(2012)\end{array}$ \\
\hline & Nitrate $\left(\mathrm{NO}_{3}^{-}\right)$ & UV visible spectrophotometer & $\begin{array}{l}\text { Potassium nitrate (KNO3), Phenol disulponic acid, } \\
\text { ammonia }\end{array}$ & $\mathrm{mg} / \mathrm{L}$ & $\begin{array}{l}\text { APHA } \\
(2012)\end{array}$ \\
\hline
\end{tabular}


Pleistocene in age (Ranga Rao et al., 1988). The Siwaliks rocks mainly exposed in the study area, except the northernmost part of the study area where the Murree Formation of Early Miocene age found as Monotonous grey sandstone and grey, brown to yellowish subordinate, mudstone, siltstone and clay (Fig. 1c). The Siwaliks rocks as classified Lower, Middle and Upper Siwaliks are found in the study area, the Lower Siwalik composed of red mudstone and fine medium grained grey, green sandstone of Middle Miocene Age (Table 1). The Middle Siwaliks Upper Miocene Age composed of Medium to coarse-grained sandstones and subordinate grey brown mudstone with coarsening upward in sequence and comparatively softer to Lower Siwaliks. The Upper Siwaliks of Pliocene to Middle Pleistocene age study area further classified into three formation Parmandal Sandstone, Nagrota Silt, and Boulder Conglomerate which exquisitely found in the study area. The Jammu alluvium is the part of the Indo-Gangetic plains are part of the younger and older alluvium deposited plains of study area and mostly act as recharge cum discharge zone (Jasrotia and Kumar 2014b; Jasrotia et al., 2019a,b).

\section{Data and methodology}

\subsection{Sampling and analytical procedures}

Spring samples of 60 locations were collected and analyzed for various hydrochemical parameters such as $\mathrm{pH}$, electrical conductivity (EC), total dissolved solids (TDS), total hardness (TH) as $\mathrm{CaCO}_{3}$, calcium $\left(\mathrm{Ca}^{2+}\right)$, magnesium $\left(\mathrm{Mg}^{2+}\right)$, sodium $\left(\mathrm{Na}^{+}\right)$, potassium $\left(\mathrm{K}^{+}\right)$, chloride $\left(\mathrm{Cl}_{-}\right)$, sulphate $\left(\mathrm{SO}_{4}^{2-}\right)$, nitrate $\left(\mathrm{NO}_{3}^{-}\right)$, fluoride $\left(\mathrm{F}^{-}\right)$. Environment sensitive index such as $\mathrm{pH}$ (hydrogen ion concentration), electrical conductance (EC), total dissolved solids (TDS) were measured in the field at the time of sample collection using a $\mathrm{pH} / \mathrm{EC} / \mathrm{TDS}$ meter. The detail analytical procedure for hydrochemical quality given in Table 2. The location of each spring was taken into the GIS environment, and the results of each parameter analyzed were added to the concerned wells.

\subsection{Water quality index}

The water quality index (WQI) was also evaluated to determine the suitability for drinking purposes (Horton, 1965; Ramakrishnaiah et al., 2009; Varol and Davraz, 2015; Saha et al., 2018; Adimalla and Taloor, 2020). The WQI is a mathematical effectual tool, which provides a comprehensive model of the groundwater quality and is used to present large quantities of water quality data into a single number developed by Horton (1965). WQIs are effective tool to estimate the overall water quality for drinking purposes by examining individual water quality parameters where all calculated cations, anions, $\mathrm{pH}, \mathrm{EC}$ and TDS were taken into account to determine the water quality index by using the three set WQI calculations which includes (a) assignment of weights, (wi) (based on equation (1)) to each water quality parameter involved; (b) calculation of relative weights (Wi) and (c) quality rating scale calculation (Qi) (based on equation (2)):

$\mathrm{Wi}=w i / \sum_{i=1}^{n} w i$

$\mathrm{Qi}=\frac{\mathrm{Ci}}{\mathrm{Si}} \times 100$

where Qi is the quality rating for each chemical parameter $\mathrm{i}, \mathrm{Ci}$ is the concentration of each chemical parameter $\mathrm{i}$ in each water sample (mg/ $\mathrm{L}$ ), $\mathrm{n}$ is the total number of parameters, and $\mathrm{Si}$ is the Indian drinking water standard (BIS, 2012) for chemical parameter i. Assigning the weights for each chemical parameter is the most important part, which determines the significance of a water quality parameter for drinking uses. Assigning the weights for each chemical parameter is the most important part, which determines the significance of a water quality
Table 3

Relative weight of hydrochemical parameters.

\begin{tabular}{lllll}
\hline $\begin{array}{l}\text { Chemical } \\
\text { parameter }\end{array}$ & Units & $\begin{array}{l}\text { BIS } \\
(2012)\end{array}$ & $\begin{array}{l}\text { Weight } \\
\text { (wi) }\end{array}$ & $\begin{array}{l}\text { Relative weight } \\
\text { Wi }=\text { wi } / \sum_{i=1}^{n} W i\end{array}$ \\
\hline $\mathrm{pH}$ & - & $6.5-8.5$ & 3 & 0.075 \\
$\mathrm{TDS}$ & $\mathrm{mg} / \mathrm{L}$ & 500 & 4 & 0.100 \\
$\mathrm{TH}$ & $\mathrm{mg} / \mathrm{L}$ & 200 & 3 & 0.075 \\
$\mathrm{Ca}^{2+}$ & $\mathrm{mg} / \mathrm{L}$ & 200 & 3 & 0.075 \\
$\mathrm{Mg}^{2+}$ & $\mathrm{mg} / \mathrm{L}$ & 30 & 3 & 0.075 \\
$\mathrm{Na}^{+}$ & $\mathrm{mg} / \mathrm{L}$ & 200 & 2 & 0.050 \\
$\mathrm{~K}^{+}$ & $\mathrm{mg} / \mathrm{L}$ & 12 & 2 & 0.050 \\
$\mathrm{~F}^{-}$ & $\mathrm{mg} / \mathrm{L}$ & 1.5 & 5 & 0.125 \\
$\mathrm{HCO}_{3}^{-}$ & $\mathrm{mg} / \mathrm{L}$ & 120 & 3 & 0.075 \\
$\mathrm{SO}_{4}^{2-}$ & $\mathrm{mg} / \mathrm{L}$ & 200 & 3 & 0.075 \\
$\left(\mathrm{Cl}^{-}\right.$ & $\mathrm{mg} / \mathrm{L}$ & 250 & 4 & 0.100 \\
$\mathrm{NO}_{3}^{-}$ & $\mathrm{mg} / \mathrm{L}$ & 45 & 5 & 0.125 \\
& & & $\sum w i=40$ & $\sum \mathrm{Wi}=1$ \\
\hline
\end{tabular}

parameter for drinking uses. For each of 11 parameters, a weight (wi) has been assigned according to its relative importance in the overall quality of drinking water, as shown in Table 3. The most significant parameters have a weight of 5 and the least significant have a weight of 2 . In the study, the maximum weight of 5 has been assigned to total dissolved solids, nitrate and fluoride, due to their major importance in water quality assessment (Ramakrishnaiah et al., 2009). Then, water quality sub-indices (SIi) for each chemical parameter is computed by equation (3), and the WQI is determined by equation (4):

$\mathrm{SIi}=\mathrm{Wi} \times \mathrm{Qi}$

$\mathrm{WQi}=\sum_{i=1}^{n} S I i$

Based on the spatial statistical analysis in the GIS, using ARC Map 10.5 software. The quality maps of the different cations, anion, $\mathrm{pH}$ and TDS were prepared in the GIS environment using the inverse distance weighting (IDW, one of the highly used for the random sample data.

\subsection{Irrigation water quality}

Irrigation water quality was computed by the following as under.

For the irrigation water quality measurement Sodium absorption ration (SAR), which is a kind of sodium hazard in the use of water for irrigation was determined by equation (5) (Karanth, 1987)

$\mathrm{SAR}=\frac{\mathrm{Na}^{+}}{\left(\sqrt{\left(\mathrm{Ca} 2++M g^{2+}\right)}\right) / 2}$

The concentrations of cations are expressed in meq/L.

The sodium percent in water is another common parameter (Wilcox, 1955) which is extensively used to evaluate the water for irrigation suitability parameter computed to evaluate the suitability for irrigation computed by equation (6):

$\mathrm{Na} \%=\times 100 \frac{\mathrm{Na}^{+}+\mathrm{K}^{+}}{\mathrm{Ca} 2++\mathrm{Mg}^{2+}+\mathrm{Na}^{+}+\mathrm{K}^{+}}$

The concentrations of cations are expressed in meq/L.

The concentrations of cations are expressed in meq/L.

Besides this, irrigation water can also be classified based on RSC. When the sum of carbonate and bicarbonate is in excess over the alkaline earths chiefly calcium and magnesium, in excess of permissible limits affects irrigation adversely according to Eaton (1950) and Richards (1954).

$\mathrm{RSC}=(\mathrm{CO} 32-+\mathrm{HCO} 3-)-(\mathrm{Ca} 2++\mathrm{Mg} 2+) \mathrm{meq} / \mathrm{L}$ 
Table 4

Chemical composition of the spring water quality.

\begin{tabular}{|c|c|c|c|c|c|c|c|c|c|c|c|c|c|c|c|c|}
\hline S No. & $\mathrm{pH}$ & $\mathrm{EC}$ & TDS & TA & TH & $\mathrm{Ca}^{2+}$ & $\mathrm{Mg}^{2+}$ & $\mathrm{Na}^{+}$ & $\mathrm{K}^{+}$ & $\mathrm{HCO}_{3}^{-}$ & $\mathrm{Cl}^{-}$ & $\mathrm{F}^{-}$ & $\mathrm{SO}_{4}^{2-}$ & $\mathrm{NO}_{3}^{-}$ & Ionic balance & WQI \\
\hline 1 & 7.7 & 293 & 153 & 167 & 210 & 47.0 & 21.0 & 9.4 & 1.3 & 205.0 & 16.0 & 0.3 & 34.0 & 8.0 & -1.63 & 40 \\
\hline 2 & 7.5 & 520 & 280 & 276 & 280 & 84.2 & 16.0 & 30.0 & 1.6 & 334.0 & 18.5 & 0.5 & 27.0 & 25.0 & -0.91 & 58 \\
\hline 3 & 7.7 & 365 & 188 & 183 & 198 & 61.2 & 11.9 & 10.2 & 1.4 & 222.0 & 15.2 & 0.2 & 8.0 & 13.0 & 0.65 & 39 \\
\hline 4 & 7.7 & 498 & 258 & 260 & 282 & 88.0 & 16.0 & 10.0 & 4.3 & 338.0 & 15.3 & 0.3 & 15.8 & 9.2 & -1.67 & 53 \\
\hline 5 & 7.5 & 292 & 153 & 158 & 200 & 42.0 & 25.0 & 9.4 & 2.3 & 195.0 & 15.2 & 0.5 & 37.4 & 4.2 & 1.34 & 41 \\
\hline 6 & 7.8 & 285 & 148 & 133 & 174 & 42.6 & 18.3 & 11.3 & 1.4 & 172.9 & 7.8 & 0.2 & 42.5 & 8 & 0.97 & 36 \\
\hline 7 & 7.5 & 254 & 133 & 118 & 164 & 40.6 & 17.1 & 10 & 1.4 & 154.6 & 10.9 & 0.4 & 37.6 & 11 & 1.04 & 36 \\
\hline 8 & 7.7 & 742 & 388 & 278 & 384 & 90.7 & 40.2 & 34.8 & 2.5 & 349.8 & 64.6 & 0.1 & 34.7 & 63.9 & 0.51 & 78 \\
\hline 9 & 7.7 & 723 & 398 & 353 & 404 & 10.5 & 93.7 & 34.2 & 5 & 441.3 & 43.3 & 0.1 & 38.1 & 31.4 & 0.44 & 87 \\
\hline 10 & 7.7 & 1523 & 793 & 323 & 529 & 82.7 & 60 & 25 & 2 & 404.7 & 111 & 0.1 & 35 & 12 & -2.32 & 107 \\
\hline 11 & 7.7 & 562 & 289 & 163 & 269 & 88.7 & 13.5 & 22.1 & 9.2 & 209.5 & 18.5 & 0.1 & 120 & 11.6 & 0.67 & 50 \\
\hline 12 & 7.9 & 532 & 279 & 278 & 244 & 62.6 & 23.2 & 25.8 & 1.4 & 349.8 & 11.4 & 0.1 & 2.2 & 4.5 & 0.09 & 50 \\
\hline 13 & 7.8 & 620 & 320 & 243 & 289 & 88.7 & 18.3 & 36.4 & 6 & 307.1 & 64.6 & 0.2 & 24.6 & 13.2 & 0.51 & 57 \\
\hline 14 & 7.4 & 472 & 247 & 208 & 249 & 22.5 & 48.7 & 28.1 & 3.9 & 264.4 & 18.5 & 0.1 & 71.5 & 0.9 & 0.67 & 52 \\
\hline 15 & 7.5 & 543 & 284 & 288 & 259 & 22.5 & 51.2 & 46.5 & 2.1 & 362 & 32.7 & 0.1 & 20.2 & 2.6 & 0.59 & 58 \\
\hline 16 & 7.2 & 712 & 367 & 118 & 224 & 76.6 & 9.8 & 85.8 & 7.8 & 154.6 & 175 & 0.1 & 41.1 & 9.9 & 0.46 & 49 \\
\hline 17 & 7.3 & 582 & 305 & 273 & 289 & 38.6 & 48.7 & 15 & 5 & 343.7 & 25.6 & 0.2 & 10.7 & 2.1 & 0.67 & 58 \\
\hline 18 & 7.2 & 612 & 315 & 298 & 344 & 108.7 & 19.5 & 10.4 & 16.2 & 374.2 & 11.4 & 0.1 & 56.5 & 11.1 & 0.51 & 63 \\
\hline 19 & 7.6 & 333 & 169 & 158 & 214 & 56.6 & 19.5 & 10.7 & 1.6 & 203.4 & 14.9 & 0.1 & 44.3 & 10.5 & 0.85 & 40 \\
\hline 20 & 7.7 & 763 & 398 & 328 & 374 & 114.7 & 23.2 & 42.4 & 59.6 & 410.8 & 64.6 & 0.1 & 112 & 2.1 & 0.38 & 90 \\
\hline 21 & 7.6 & 1075 & 559 & 318 & 564 & 138.8 & 54.8 & 81.2 & 2.5 & 398.6 & 157 & 0.1 & 175 & 21.2 & 0.28 & 92 \\
\hline 22 & 8.4 & 296 & 154 & 118 & 189 & 38.6 & 24.4 & 17.4 & 2.2 & 154.6 & 39.8 & 0.2 & 45.1 & 3.9 & 0.82 & 38 \\
\hline 23 & 7.4 & 465 & 242 & 238 & 249 & 34.6 & 41.4 & 16.4 & 2.5 & 301 & 14.9 & 0.1 & 20.5 & 2.1 & 0.76 & 50 \\
\hline 24 & 7.5 & 280 & 143 & 78 & 184 & 42.6 & 20.8 & 10 & 1.3 & 105.8 & 22 & 0.1 & 71.3 & 22.6 & 1.13 & 36 \\
\hline 25 & 7 & 295 & 154 & 93 & 164 & 44.6 & 14.7 & 15.2 & 3.9 & 124.1 & 25.6 & 0.1 & 47 & 22.9 & 1.04 & 36 \\
\hline 26 & 7.6 & 455 & 237 & 233 & 249 & 30.6 & 43.9 & 17.9 & 1 & 294.9 & 18.5 & 0.1 & 22.7 & 1 & 0.78 & 49 \\
\hline 27 & 7.6 & 240 & 123 & 113 & 154 & 48.6 & 9.8 & 6 & 1.9 & 148.5 & 11.4 & 0.2 & 25.6 & 9.1 & 1.36 & 31 \\
\hline 28 & 8.2 & 240 & 195 & 218 & 214 & 36.6 & 31.7 & 17.8 & 1.4 & 276.6 & 11.4 & 0.1 & 8.7 & 7.2 & 0.83 & 45 \\
\hline 29 & 7.7 & 718 & 372 & 353 & 304 & 28.6 & 58.5 & 62.1 & 2.1 & 441.3 & 43.3 & 0.1 & 7.3 & 17.6 & 0.55 & 72 \\
\hline 30 & 7.7 & 563 & 294 & 288 & 284 & 30.6 & 52.4 & 12 & 18.3 & 362 & 11.4 & 0.1 & 17.2 & 7.4 & 0.66 & 66 \\
\hline 31 & 7.7 & 476 & 247 & 223 & 274 & 30.6 & 49.9 & 24.9 & 2.7 & 282.7 & 29.1 & 0.4 & 58.8 & 0.9 & 0.51 & 56 \\
\hline 32 & 7.7 & 921 & 476 & 358 & 504 & 66.6 & 84 & 41.6 & 23.5 & 447.4 & 85.9 & 0.1 & 64 & 90.9 & 0.33 & 116 \\
\hline 33 & 7.6 & 576 & 299 & 313 & 299 & 14.5 & 65.7 & 28.7 & 2.2 & 392.5 & 14.9 & 0.4 & 19.2 & 5.8 & 0.43 & 66 \\
\hline 34 & 7.2 & 570 & 297 & 273 & 274 & 22.5 & 54.8 & 12.9 & 2.2 & 343.7 & 18.5 & 0.1 & 2.2 & 2.5 & 0.00 & 56 \\
\hline 35 & 7.3 & 358 & 185 & 183 & 239 & 36.6 & 37.8 & 7.6 & 1.4 & 233.9 & 11.4 & 0.5 & 43.2 & 9.6 & 0.62 & 49 \\
\hline 36 & 8.2 & 680 & 357 & 308 & 319 & 108.7 & 13.5 & 39.8 & 5.2 & 386.4 & 7.8 & 0.1 & 65.5 & 24 & 0.54 & 64 \\
\hline 37 & 7.7 & 290 & 154 & 138 & 164 & 58.6 & 6.2 & 7.5 & 2 & 179 & 11.4 & 0.1 & 19 & 4.3 & 1.14 & 31 \\
\hline 38 & 7.8 & 640 & 331 & 348 & 354 & 112.7 & 19.5 & 24.7 & 6.9 & 435.2 & 14.9 & 0.1 & 37.5 & 3.5 & 0.49 & 62 \\
\hline 39 & 8 & 845 & 440 & 448 & 389 & 84.7 & 45.1 & 74 & 8.7 & 557.2 & 32.7 & 0.1 & 57.7 & 1.6 & 0.40 & 81 \\
\hline 40 & 7.7 & 280 & 149 & 98 & 364 & 46.6 & 62.1 & 7.6 & 1.1 & 130.2 & 7.8 & 0.6 & 251 & 7.4 & 0.40 & 58 \\
\hline 41 & 7.7 & 725 & 367 & 363 & 359 & 74.6 & 43.9 & 24.4 & 1.7 & 453.5 & 22 & 0.5 & 6.4 & 9.8 & 0.40 & 71 \\
\hline 42 & 7.8 & 955 & 497 & 458 & 444 & 95 & 82 & 22 & 2 & 590 & 26 & 0.4 & 52 & 15.5 & 3.03 & 108 \\
\hline 43 & 7.9 & 440 & 227 & 238 & 284 & 40.6 & 46.3 & 16.7 & 2.2 & 301 & 11.4 & 0.1 & 58.1 & 3.7 & 0.66 & 53 \\
\hline 44 & 7.8 & 720 & 367 & 348 & 374 & 60.6 & 56 & 39.4 & 1.3 & 435.2 & 18.5 & 0.1 & 56.1 & 28.9 & 0.44 & 76 \\
\hline 45 & 8 & 705 & 372 & 348 & 354 & 72.6 & 43.9 & 35.5 & 4.6 & 435.2 & 36.2 & 0.1 & 2 & 37.7 & 0.49 & 75 \\
\hline 46 & 7.7 & 1305 & 679 & 178 & 189 & 74.6 & 3.7 & 93.3 & 6.5 & 227.8 & 61.1 & 0.3 & 17 & 139.9 & 1.03 & 87 \\
\hline 47 & 7.7 & 385 & 206 & 188 & 199 & 32.6 & 30.5 & 10.4 & 1.6 & 240 & 7.8 & 0.1 & 16.1 & 2.8 & 0.97 & 41 \\
\hline 48 & 7.5 & 685 & 357 & 368 & 404 & 42.6 & 74.3 & 16.3 & 9.9 & 459.6 & 14.9 & 0.1 & 51.5 & 4.8 & 0.49 & 78 \\
\hline 49 & 7.8 & 270 & 142 & 148 & 143 & 26.5 & 20.6 & 8.6 & 3.3 & 191.2 & 7.8 & 0.1 & 2.2 & 2.2 & 0.50 & 33 \\
\hline 50 & 7.7 & 354 & 185 & 143 & 191 & 24.5 & 33.5 & 6.9 & 2.6 & 185.1 & 7.8 & 0.1 & 36.1 & 15.5 & 0.97 & 42 \\
\hline 51 & 7.2 & 512 & 269 & 228 & 206 & 56.6 & 17.5 & 9.9 & 13.8 & 288.8 & 7.8 & 0.1 & 2.2 & 0.9 & 0.28 & 47 \\
\hline 52 & 7.6 & 260 & 137 & 123 & 119 & 44.6 & 3.8 & 14.7 & 1.6 & 160.7 & 11.4 & 0.2 & 5.9 & 3.1 & 1.25 & 28 \\
\hline 53 & 7.9 & 296 & 156 & 133 & 115 & 26.5 & 13.6 & 6.8 & 43.2 & 172.9 & 7.8 & 0.1 & 31.7 & 2.6 & 1.06 & 48 \\
\hline 54 & 7.7 & 233 & 123 & 103 & 124 & 26.5 & 15.9 & 10.8 & 0.9 & 136.3 & 14.9 & 0.1 & 11.8 & 8.5 & 1.31 & 29 \\
\hline 55 & 7.8 & 300 & 158 & 93 & 115 & 34.6 & 8.7 & 25.9 & 5.1 & 124.1 & 25.6 & 0.1 & 40.3 & 0.9 & 1.15 & 29 \\
\hline 56 & 7.7 & 270 & 141 & 113 & 172 & 32.6 & 24 & 9.6 & 2.4 & 148.5 & 18.5 & 0.1 & 47.1 & 3.1 & 1.09 & 34 \\
\hline 57 & 7.7 & 302 & 161 & 78 & 177 & 40.6 & 20.3 & 9.4 & 2 & 105.8 & 7.8 & 0.1 & 73.7 & 35.5 & 1.08 & 40 \\
\hline 58 & 7.7 & 260 & 137 & 98 & 153 & 30.6 & 20.5 & 10 & 0.9 & 130.2 & 18.5 & 0.1 & 38.6 & 7.1 & 1.27 & 32 \\
\hline 59 & 7.8 & 440 & 227 & 138 & 201 & 26.5 & 34.6 & 28.1 & 1.5 & 179 & 36.2 & 0.1 & 44 & 29.2 & 0.76 & 48 \\
\hline 60 & 7.5 & 656 & 333 & 310 & 314 & 110.5 & 14.8 & 41.5 & 5.3 & 388.2 & 8.7 & 0.3 & 67.2 & 26.9 & 1.26 & 65 \\
\hline
\end{tabular}

All concentration in mg/l except $\mathrm{pH}$ and EC; location of the samples are shown in Fig. 1c; WQI: Water Quality Index.

\subsection{Discharge measurement}

The discharge of the spring water fluctuates seasonally and mainly depends on rainfall pattern in the recharge area and variation in the amount of rainwater that is able to in-filtrate the ground. In some studies, we have found that anthropogenic activity affects the spring discharge (Hao et al., 2016) where the measure of concentration discharge have also been well documented with arsenic occurrence (Reyes et al., 2015) We measure the discharge of spring during the summer (pre-monsoon) at that time the flow was quite low so we use this simple and accurate. The discharge measurement of the springs were also carried out using the container/stopwatch method, where flow (Q) can be captured into a container of known volume $(\mathrm{V})$, one of the most straightforward methodologies for determining discharge is to time $(\mathrm{t})$ the filling of the container and calculate flow using the discharge equation

$\mathrm{Q}=\mathrm{V} / \mathrm{t}$ 
Table 5

Comparison of the quality parameters of spring water of the study area with WHO (1984) and BIS (2012) standard for drinking purpose.

\begin{tabular}{|c|c|c|c|c|c|c|c|}
\hline $\begin{array}{l}\text { S } \\
\text { No. }\end{array}$ & $\begin{array}{l}\text { Water Quality } \\
\text { parameters unit }\end{array}$ & $\begin{array}{l}\text { WHO (1984) } \\
\text { Highest desirable } \\
\text { limit }\end{array}$ & $\begin{array}{l}\text { Maximum } \\
\text { permissible limit }\end{array}$ & $\begin{array}{l}\text { BIS (2012)Highest } \\
\text { desirable limit }\end{array}$ & $\begin{array}{l}\text { Maximum } \\
\text { permissible limit }\end{array}$ & $\begin{array}{l}\text { Concentration in the } \\
\text { study area }\end{array}$ & Undesirable effect \\
\hline 1 & $\mathrm{pH}$ & 7.0 & 8.5 & 6.5 & 8.5 & $7-8.4$ & $\begin{array}{l}\text { Cause skin, eye and mucous } \\
\text { membrane irritation }\end{array}$ \\
\hline 2 & TDS (mg/L) & 500 & 1500 & 500 & 2000 & $123-793$ & Gastrointestinal irritation \\
\hline 3 & Calcium (mg/L) & 75 & 200 & 75 & 200 & $10.5-138.8$ & Scale formation \\
\hline 4 & Magnesium (mg/L) & 50 & 150 & 30 & 100 & $3.7-93.7$ & Diarrhea, abdominal cramping \\
\hline 5 & Potassium (mg/L) & & & - & & $0.9-59.9$ & Bitter taste \\
\hline 6 & Sodium (mg/L) & & 200 & - & - & $6-93.3$ & High blood pressure \\
\hline 7 & Bicarbonate (mg/L) & & & & & $105.8-590$ & Kidney failure internal bleeding \\
\hline 8 & Chloride (mg/l) & 200 & 600 & 250 & 1000 & $7.8-175$ & Salty taste \\
\hline 9 & Sulphate (mg/L) & 200 & 400 & 200 & 400 & $2-251$ & Laxative effect \\
\hline 10 & Nitrate (mg/L) & 45 & & 45 & - & $0.9-139.9$ & Methaemoglobinaemia \\
\hline 11 & Fluoride (mg/L) & & & 1 & 1.5 & $0.1-0.6$ & Fluorosis \\
\hline 12 & $\begin{array}{l}\text { Total Hardness as } \\
\mathrm{CaCO}_{3}(\mathrm{meq} / \mathrm{L})\end{array}$ & 100 & 500 & 200 & 600 & $115-864$ & $\begin{array}{l}\text { Encrustation in water supply and } \\
\text { adverse effect }\end{array}$ \\
\hline
\end{tabular}

Table 6

Water classifications on the basis of TDS (Freeze and Cherry, 1979; Davis and DeWiest, 1966) and TH (,b).

\begin{tabular}{|c|c|c|c|c|}
\hline Parameters & Range & $\begin{array}{l}\text { Water type/ } \\
\text { Classification }\end{array}$ & $\begin{array}{l}\text { No. of } \\
\text { sample }\end{array}$ & $\begin{array}{l}\% \text { of } \\
\text { samples }\end{array}$ \\
\hline \multirow[t]{4}{*}{ TH (mg/L) (,b) } & $<75$ & Soft & & \\
\hline & $75-150$ & Moderately hard & 5 & 8 \\
\hline & $150-300$ & Hard & 55 & 92 \\
\hline & $>300$ & Very hard & & \\
\hline \multirow{4}{*}{$\begin{array}{l}\text { TDS (mg/L) } \\
\text { (Davis and } \\
\text { DeWiest, } \\
\text { 1966) }\end{array}$} & $<500$ & $\begin{array}{l}\text { Desirable for } \\
\text { drinking }\end{array}$ & 57 & 95 \\
\hline & $500-1000$ & $\begin{array}{l}\text { Permissible for } \\
\text { drinking }\end{array}$ & 3 & 5 \\
\hline & $1000-3000$ & $\begin{array}{l}\text { Useful for } \\
\text { irrigation }\end{array}$ & & \\
\hline & $>3000$ & $\begin{array}{l}\text { Unfit for drinking } \\
\text { and irrigation }\end{array}$ & & \\
\hline \multirow{4}{*}{$\begin{array}{l}\text { TDS (mg/L) } \\
\text { (Freeze and } \\
\text { Cherry, 1979) }\end{array}$} & $<1000$ & Fresh & 60 & 100 \\
\hline & $1000-10,000$ & Brackish & & \\
\hline & $10,000-100000$ & Saline & & \\
\hline & $>100,000$ & Brine & & \\
\hline
\end{tabular}

\section{Results and discussions}

\subsection{Assessment of spring water suitability for drinking purposes}

It is essential to distinguish the quality of spring for drinking and other domestic purposes. Various water quality parameters and analytical results are presented in Table 4 and the values are compared with standard values of the Bureau of India Standards (BIS, 2012), as shown in Table 5. The $\mathrm{pH}$ value ranged from 7 to 8.4, with a mean of 7.66 (Table 4). The $\mathrm{pH}$ values range between 6.5 and 7.9 indicates the water is acidic to slightly alkaline in nature. The total dissolved solids (TDS) ranges between 123 and $793 \mathrm{mg} / \mathrm{l}$ within the highest desirable limit indicate the water is suitable for livestock. ,b) classification, based on the hardness the spring samples of study area falls under moderately hard (8\%) to hard category (92\%) (Table 6). Furthermore, TDS values were classified according to Freeze and Cherry (1979), as shown in Table 6, indicating all the spring samples were under fresh water category. The classification of (Davis and DeWiest, 1966) indicate that 95\% samples are under desirable for drinking water and only $5 \%$ are under the permissible category. The calcium varies from 10.5 to 138.5 with $73 \%$ samples are under the desirable limit and $27 \%$ samples fall in the permissible limit (BIS, 2012). The magnesium varies from 3.7 to 93.7 with $53 \%$ fall in the desirable category and $47 \%$ fall in the permissible limit. The sodium varies from 6 to 93.3 and potassium varies from 0.9 to 59.9 in the study area. Among the anion bicarbonate is the dominant element varies from 105 to 590 , chloride varies from 7.8 to 175 , sulphate varies 2 to 251 , nitrate varies 0.9 to 139.9 and fluoride varies from 0.1 to 0.6 in the study area.

The Piper trilinear diagram (Piper, 1953) and Gibbs diagram (1970) were plotted to accentuates the spring water quality. The Piper plot of the spring samples falls in the field 1 and 3 which highlights that alkaline earth exceeds alkalies, weak acids exceeds strong acids respectively (Fig. 2). The major ion chemistry is dominated major ion chemistry is dominated by $\mathrm{Ca}^{2+}, \mathrm{Mg}^{2+}, \mathrm{HCO}_{3}^{-}$and $\mathrm{SO}_{2}^{4}$ ions in the spring waters. The dissolution of carbonate rocks enriches the water in $\mathrm{Ca}^{2+}$ and $\mathrm{Mg}^{2+}$ ions. The $\mathrm{Ca} / \mathrm{Mg}$ molar ratio of spring water indicates the dissolution of calcite and dolomite from the geological formation. In the Gibbs ratio the relation to three mechanisms i.e. evaporation dominance, rock dominance and precipitation dominance controlling water chemistry. The Gibb's ratio $\mathrm{Cl}^{-} /\left(\mathrm{Cl}^{-}+\mathrm{HCO}_{3}^{-}\right)$for anion (Fig. 3a) and ratio $\mathrm{Na}^{+}+\mathrm{K}^{+} /\left(\mathrm{Na}^{+}+\mathrm{K}^{+}+\mathrm{Ca}^{2+}\right)$ for cation (Fig. $\left.3 \mathrm{~b}\right)$ exhibit that the water is mainly governed by rock dominance. The carbonate mineral dissolution may be diminished during the travel of groundwater from the recharge areas towards the thicker parts of the aquifer because of the lack of carbon dioxide.

\subsection{GIS based spatial water quality}

The GIS is an efficient tool to represent the data spatially ways and widely used by number of researchers around the world in the last four decades for mapping of the physical and chemical parameters. In the present study it found that the spatial spring water quality distribution of physical parameter $\mathrm{PH}$ (Fig. 4a) shows that most of the area under the desirable limit except a small patch in the southern part of the study area TDS (Fig. 4b) shows that except a small patch in the hilly area, the TDS is under the desirable limit. The spatial distribution of the chemical parameters (Fig. 4c-i) show that most of the area is under the desirable limit except a few pockets which are above the desirable/permissible limit.

\subsection{Water quality index (WQI)}

Groundwater samples $(n=60)$ and its WQI values are presented in Table 3. Therefore, the groundwater quality status can be categorized into five types (Ramakrishnaiah et al., 2009; Adimalla and Taloor, 2020) based on WQI values, namely excellent water $(<150)$, good water (150-200), poor water (200-250), very poor water (250-300) and water unsuitable for drinking ( $>300$ ) (Ramakrishnaiah et al., 2009). The computed WQI values ranged from 28 to 116 (Table 4). As per the 

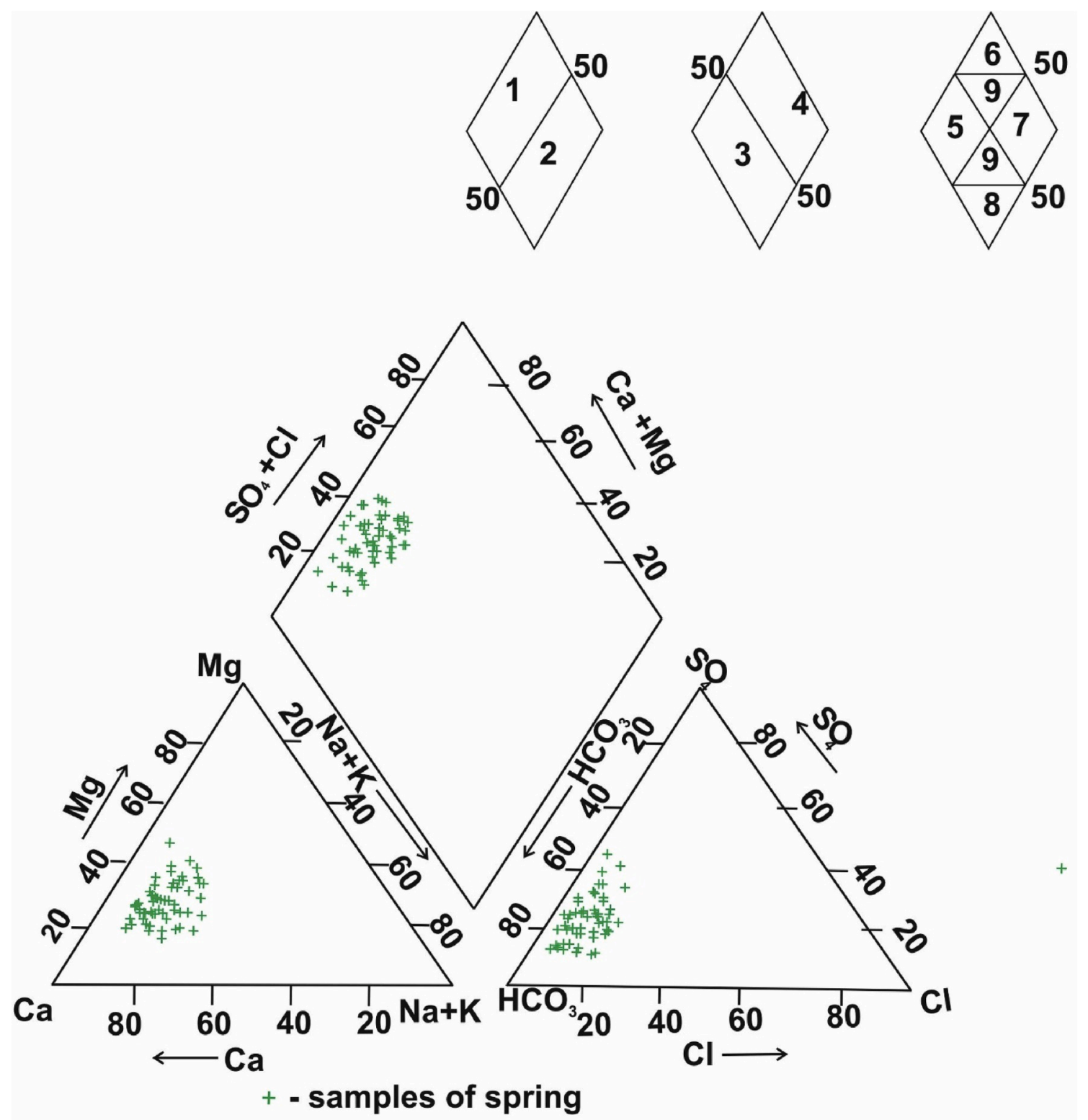

Fig. 2. Geochemical classification of groundwater based on Piper-Trilinear diagram.

classification of WQI $27 \%$ of the total spring samples fell under the excellent category, and $30 \%$ of the spring sample belongs to good water category for drinking purposes. Moreover, 3\%of groundwater samples were found of poor water quality (Table 7). The GIS based spatial analysis were performed using kriging-interpolation to determine the spatial distribution water quality index (WQI) map of the study area (Fig. 5). The spatial map shows that most of the area falls under the excellent to good categories where two small pockets found in the north and north west are under the poor category. It is also found that no sample in the study area falls in the very poor and not suitable drinking water categories.

\subsection{Evaluation of spring water suitability for irrigation purposes}

Evaluation of spring water quality is an important and vital for the study area as the southern portion is completed dominated by the agriculture activities. For the better understanding of the irrigation water quality the well-established USSL diagram (1954), Sodium absorption ratio (SAR), Sodium percentage $(\mathrm{Na} \%)$ and Residual sodium carbonate (RSC), were chosen to understand the suitability for irrigation purposes. The surplus amount of sodium concentration in water, leads to the formation of alkaline soil, and the high salt concentration, which results in the development of saline soil. Besides this, dissolved ion such as sodium, bicarbonate, and carbonate in irrigation water affects plants growth and reduce productivity of crops. The EC and $\mathrm{Na}^{+}$concentration are important in classifying irrigation water. SAR of irrigation water is calculated as an index of sodium hazard and is quantified as the relative proportion of sodium $\left(\mathrm{Na}^{+}\right)$to calcium $\left(\mathrm{Ca}_{2}^{+}\right)$and magnesium $\left(\mathrm{Mg}_{2}^{+}\right)$ions in water (Richards, 1954). SAR values ranged from 0.14 to 2.06 , with an average of 0.52 (Table 9). The salinity hazard parameter (EC) ranged between 233 and $1523 \mu \mathrm{S} / \mathrm{cm}$ with an average value of $526 \mu \mathrm{S} / \mathrm{cm}$ (Tables 3 and 8), and both are used in the USSL (1954) diagram (Fig. 6). The USSL diagram shows that all the samples fall in the low alkali hazard zone where as the 3 samples (5\%) falls under the low salinity hazard, 50 (83\%) samples under the medium salinity hazard and 7 (12\%) samples fall under the high salinity hazard zone. Sodium concentration reacts with soil to reduce or enhance its permeability. Sodium is one of the common element found in the water extensively used to evaluate 


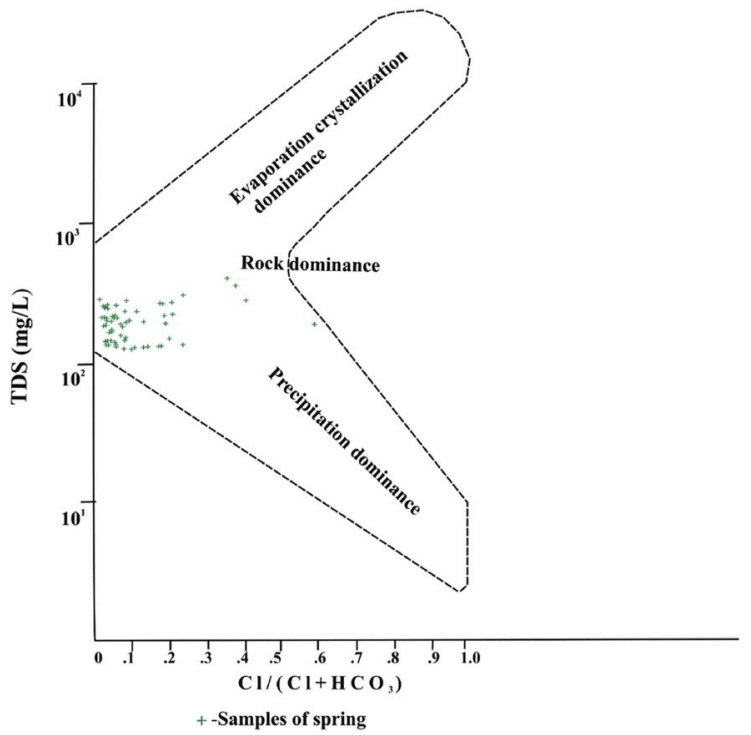

(a)

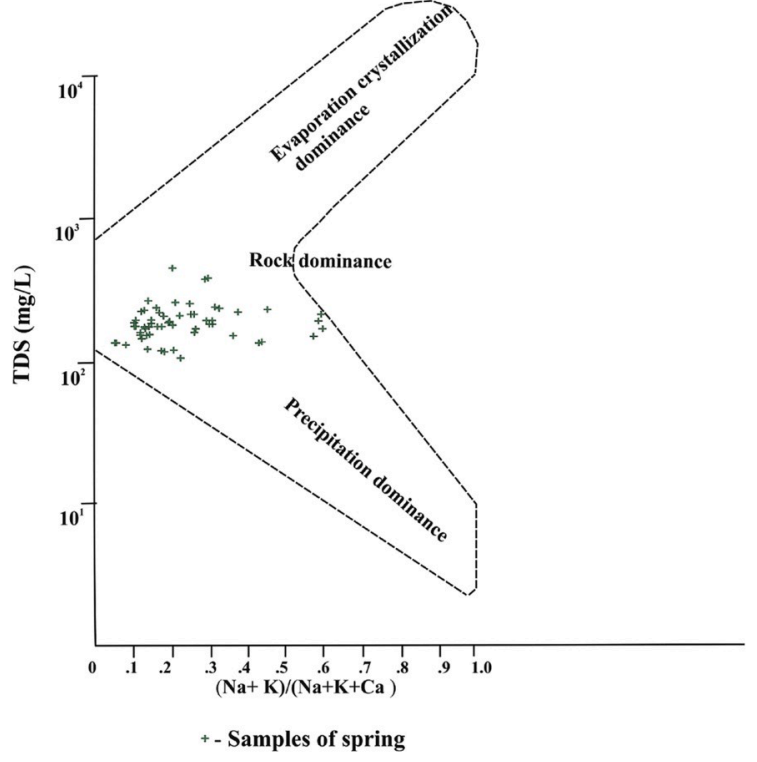

(b)

Fig. 3. (a) Gibbs ratio- $\mathrm{I} \mathrm{Cl} /(\mathrm{Cl}+\mathrm{HCO})$ for anion. (b) Gibbs ratio $\mathrm{II}-\mathrm{Na}+\mathrm{K} /(\mathrm{Na}+\mathrm{K}+\mathrm{Ca})$ for cation.

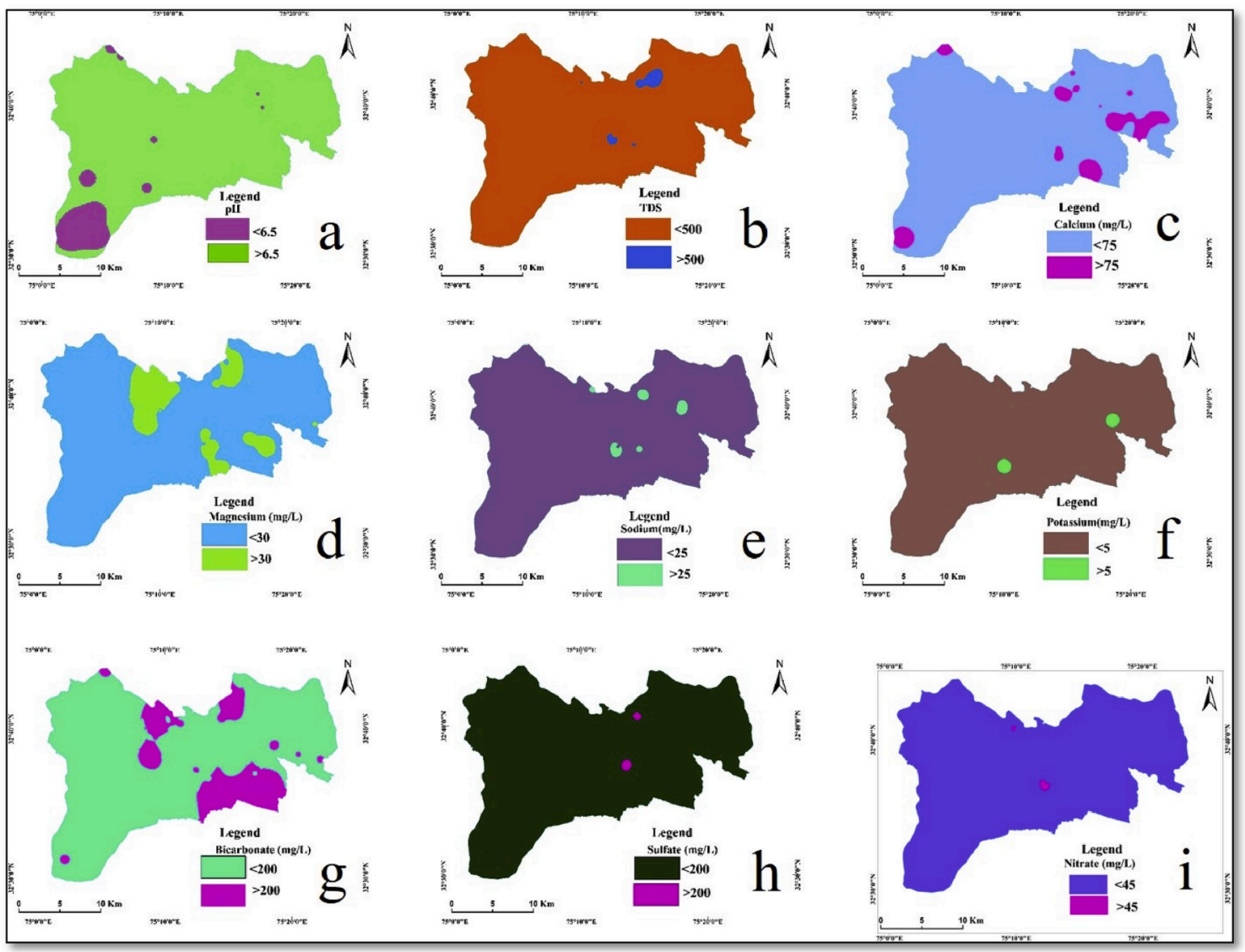

Fig. 4. Spatial distribution of different elements in the GIS environment.

irrigation water suitability. In the present study, the sodium percentage calculated through equation (6) for spring water in the study area, is plotted against EC in Wilcox diagram (Fig. 7). The spatial distribution map of the EC was prepared to know about the spatial distribution and it was found that most of the area under $<250 \mathrm{EC}$, whereas three pocket in the northern area have $250-750$ EC and a small area have a value $>$ 2750 (Fig. 8). The value of $\mathrm{Na} \%$ ranges from 0.002 to 45.93 with a mean of 16.34. The Wilcox diagram shows that 45 samples (75\%) falls under the excellent category for irrigation use of water and 15 samples (25\%) falls under the good category of sodium in the irrigation water for 
Table 7

Water quality index value type of water and percentage of sample in the study area (Ramakrishnaiah et al., 2009).

\begin{tabular}{llll}
\hline WQI Range & Type of water & Samples & $\%$ \\
\hline$<50$ & Excellent & 27 & 45 \\
50 to 100 & Good & 30 & 50 \\
100 to 200 & Poor & 3 & 5 \\
200 to 300 & Very poor & - & - \\
$>300$ & Not suitable for drinking purposes & - & - \\
\hline
\end{tabular}

irrigational purposes. The water containing a high concentration of carbonate and bicarbonate ions tends to precipitate calcium and magnesium as carbonates. As a result, the increase in the relative proportion of sodium decreases soil permeability. The residual sodium carbonate destroys the soil structure, as it restricts water and air movement through the soil. RSC is present in groundwater if the total concentrations of carbonate and bicarbonate ions exceed that of calcium and
Table 9

Groundwater quality based on sodium percentage as per Wilcox diagram.

\begin{tabular}{lllll}
\hline $\begin{array}{l}\text { S. } \\
\text { No. }\end{array}$ & $\begin{array}{l}\text { Remark on } \\
\text { quality }\end{array}$ & $\begin{array}{l}\text { Percentage of } \\
\text { sodium }\end{array}$ & $\begin{array}{l}\text { No. of } \\
\text { sample }\end{array}$ & $\begin{array}{l}\% \text { of } \\
\text { sample }\end{array}$ \\
\hline 1 & Excellent & $<20$ & 45 & 75 \\
2 & Good & $20-40$ & 15 & 25 \\
3 & Permissible & $40-60$ & & \\
4 & Doubtful & $60-80$ & & \\
5 & Unsuitable & $>80$ & & \\
\hline
\end{tabular}

magnesium ions (Richards, 1954). The RSC value classified (Raghunath, 1987a) as $>1.25$ good water type for irrigation, 1.25 to 2.5 doubtful for irrigation, $>2.5$ unsuitable for irrigation. In the present study, the RSC values varies from -5.29 to 1.19 which shows that all the samples fall under the good category.

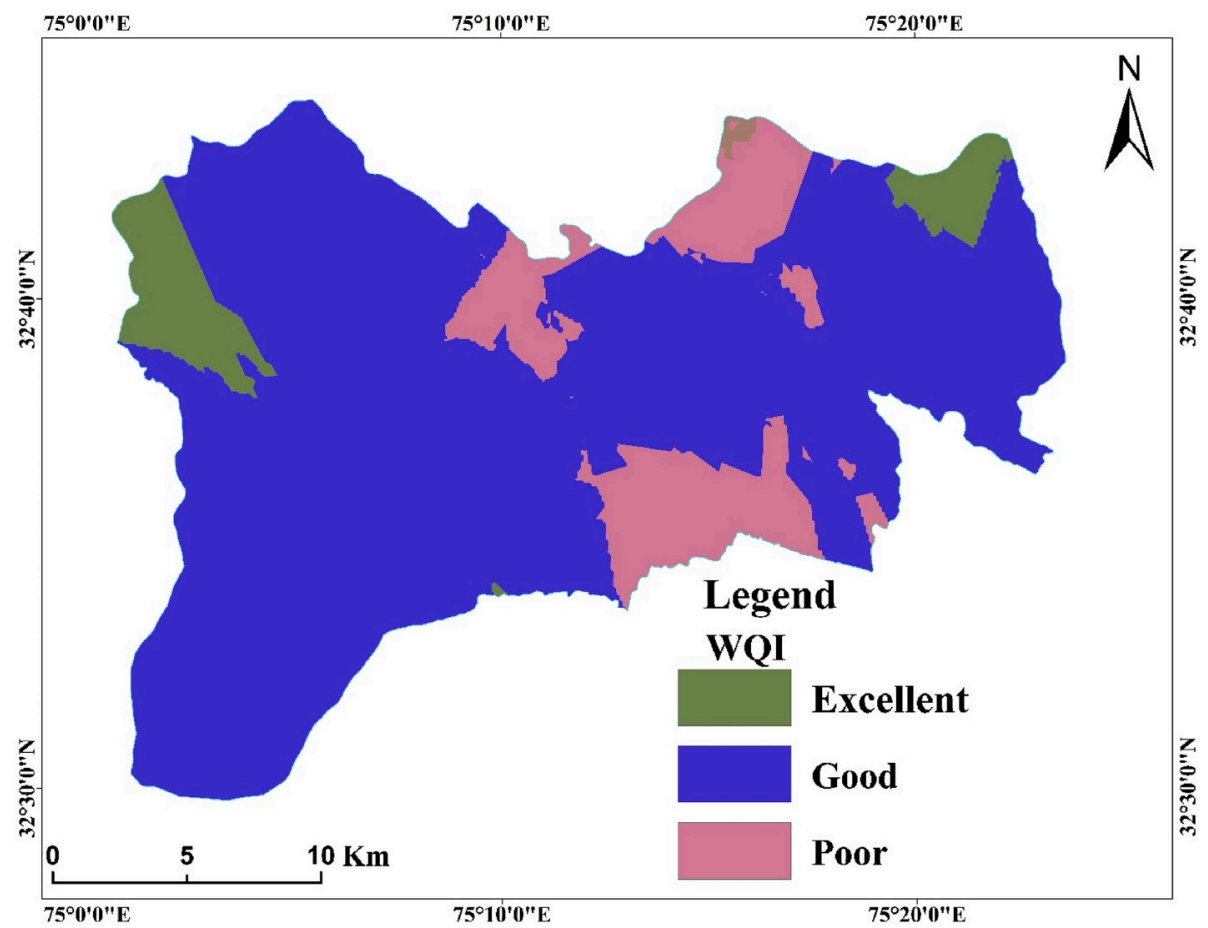

Fig. 5. Spatial distribution of water quality index (WQI) in the study area.

Table 8

Classification of groundwater quality for irrigation purpose based on SAR and EC.

\begin{tabular}{|c|c|c|c|c|c|c|}
\hline Parameters & Water type & Quality & Suitability for irrigation & Range & $\begin{array}{l}\text { No. of } \\
\text { samples }\end{array}$ & $\begin{array}{l}\% \text { samples in } \\
\text { study area }\end{array}$ \\
\hline \multirow[t]{4}{*}{$\begin{array}{l}\text { SAR (Richards } \\
\text { 1954) }\end{array}$} & Low sodium water & Excellent & $\begin{array}{l}\text { Suitable for all types of crops and all types of soils, except for those crops, } \\
\text { which are sensitive to sodium }\end{array}$ & $<10$ & 60 & 100 \\
\hline & $\begin{array}{l}\text { Medium Sodium } \\
\text { water }\end{array}$ & Good & Suitable for coarse textured or organic soil with good permeability & $10-18$ & - & \\
\hline & High sodium water & Doubtful & $\begin{array}{l}\text { Harmful for almost all type of soils, requires good drainage, high } \\
\text { leaching gypsum addition }\end{array}$ & $18-26$ & - & \\
\hline & $\begin{array}{l}\text { Very high Sodium } \\
\text { water }\end{array}$ & Unsuitable & Unsuitable for irrigation & $>26$ & - & \\
\hline \multirow[t]{4}{*}{$\begin{array}{l}\text { EC (Wilcox } \\
\text { 1955) }\end{array}$} & $\begin{array}{l}\text { Low salinity water } \\
\text { (C1) }\end{array}$ & Excellent & Suitable for all types of crops and all kinds of soils & $>250$ & 3 & 5 \\
\hline & $\begin{array}{l}\text { Medium salinity } \\
\text { water (C2) }\end{array}$ & Good & $\begin{array}{l}\text { Can be used, if a moderate amount of leaching occurs. Normal salt } \\
\text { tolerant plants can be grown without much salinity control }\end{array}$ & $250-750$ & 50 & 83 \\
\hline & $\begin{array}{l}\text { High salinity water } \\
\text { (C3) }\end{array}$ & Doubtful & Unsuitable for soil with restricted drainage & $750-2250$ & 7 & 12 \\
\hline & $\begin{array}{l}\text { Very high salinity } \\
\text { water (C4) }\end{array}$ & Unsuitable & Unsuitable for irrigation & $>2250$ & & \\
\hline
\end{tabular}




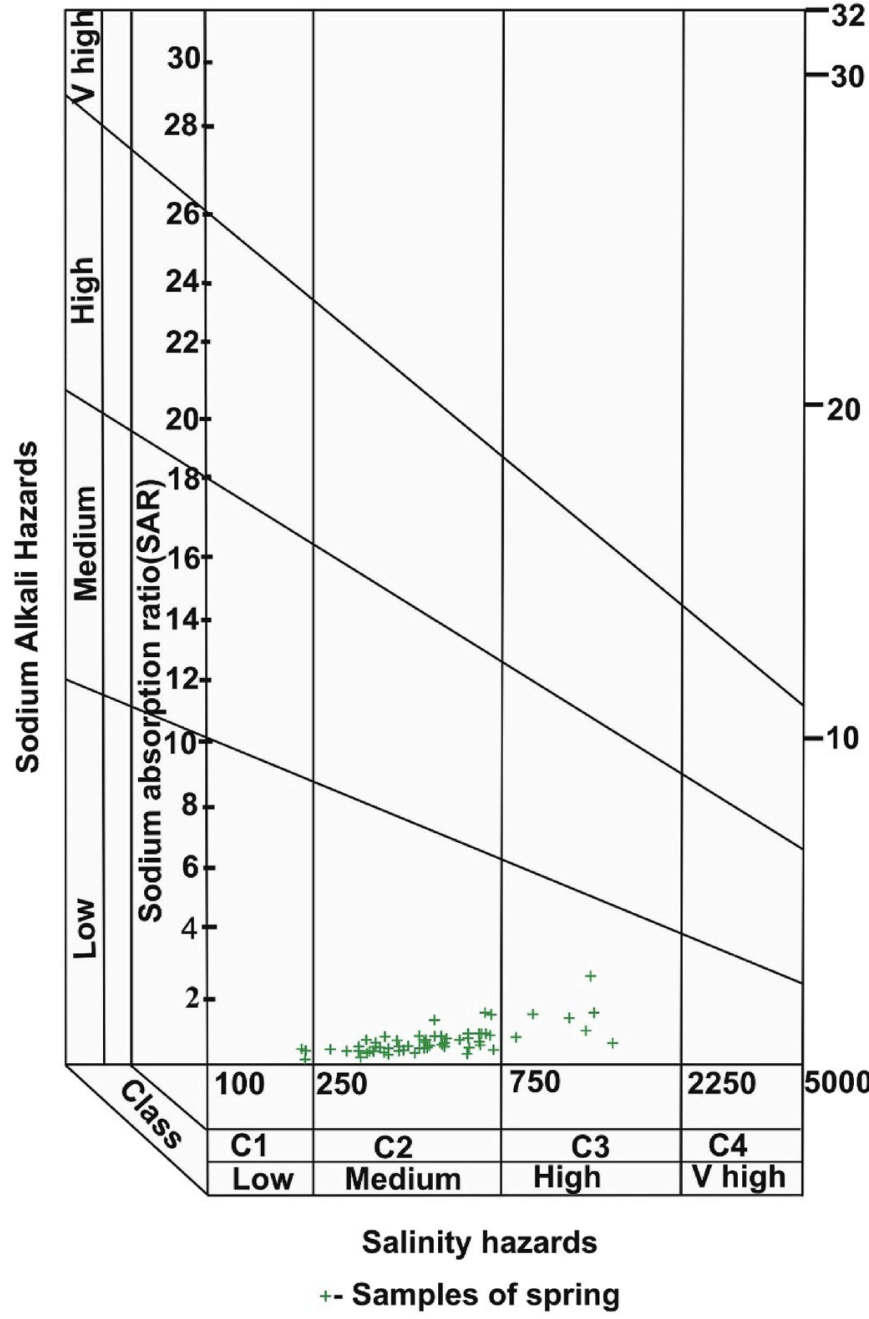

Fig. 6. Classification of irrigation water based on salinity hazards (USSL, 1954).

\subsection{Spring discharge}

Spring discharge is now a day for critical parameter for the suitable development and management of the springs. High discharge springs are considered as quite valuable and well maintained due to high utility of spring water. It is useful to embed the growing problem of spring water depletion within the context of mountain environmental systems, including the reference to mountain aquifers. Springs have provided water to the mountain communities for centuries and the revival of this traditional source of water is extremely important for the region's sustainable growth. At the same time, rivers are kept alive throughout the year, particularly in a monsoonal climate, primarily due to discharge from groundwater as springs and seeps along their river channels. In the present study area based on equation (8) the measurement of discharge indicates that 42 springs have discharge more than $20 \mathrm{~L}$ per minute second (Lps), 10 springs have discharge between 10 and 20 Lps, 5 springs have discharge between 2 and 10 Lps and 3 springs have discharge $>2$ Lps (Table 10).

\section{Conclusion}

Hydrochemical analysis of the spring water samples exhibit that $\mathrm{Ca}$ and $\mathrm{Mg}$ are dominant followed by the $\mathrm{Na}^{+}$and $\mathrm{K}^{+}$among cations. The bicarbonate is one of the most dominant anion followed by the $\mathrm{Cl}_{-}$and NO3_. Analysis of hydrochemical facies reveals two dominant facies on

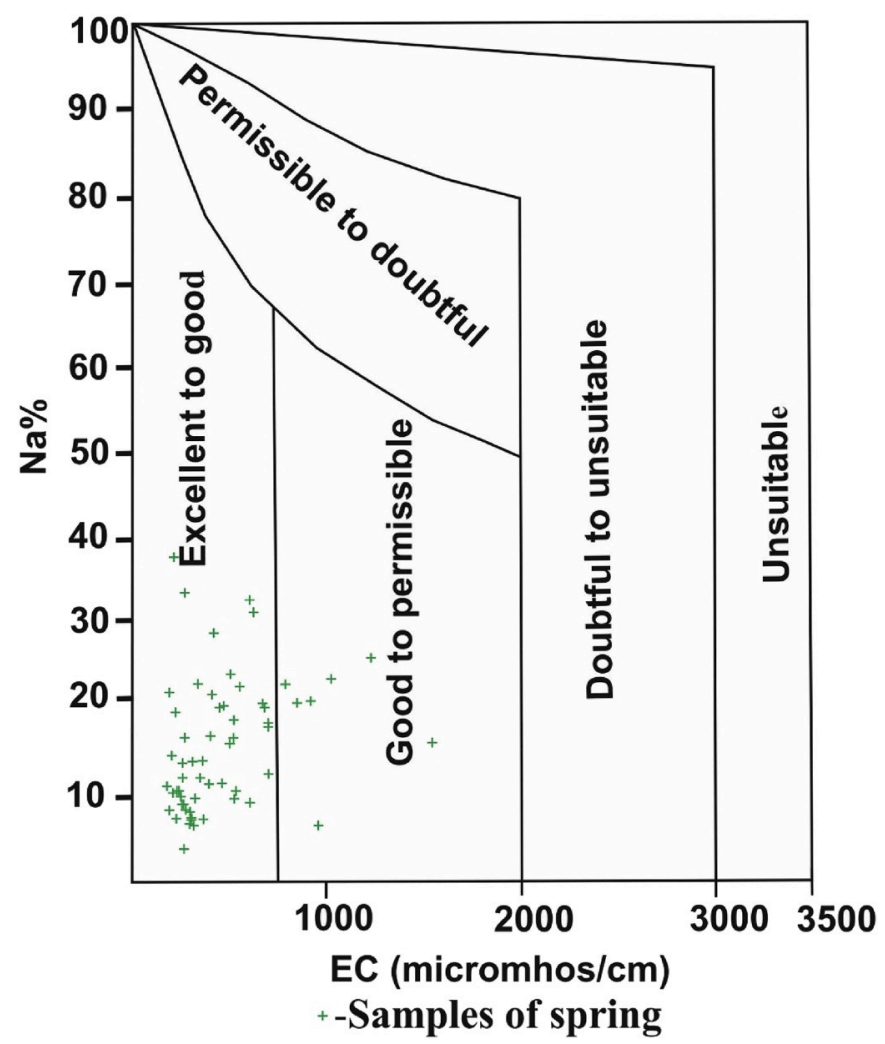

Fig. 7. Sodium percentage versus electrical conductivity (after Wilcox, 1955).

piper trilinear diagram $\mathrm{Ca}^{2+}-\mathrm{Mg}^{2+}-\mathrm{HCO}_{3}$ and $\mathrm{Ca}^{2+}-\mathrm{Mg}^{2}-\mathrm{HCO}_{3}^{-}-$ $\mathrm{SO}_{4}^{2-}$ type which depicts that the water chemistry is dominated by the alkaline earth and weak acids. The Gibbs plot shows that total dissolved solids, point towards rock dominance and suggests congruent dissolution of carbonate lithology. The high values of $\mathrm{HCO}^{-}$in spring water samples illustrate the dissolution of carbonate rocks in the recharge area due to the acidic precipitation $\left(\mathrm{CO}^{2-}\right.$ rich) and ionic enrichment. The fluoride is with the desirable limit whereas the nitrate is in the permissible limit except $3(5 \%)$ samples. The Wilcox diagram revealed that most of the spring samples are good (25\%) to excellent (75) category for irrigation. The US Salinity Laboratory diagram indicates that $83 \%$ of groundwater samples belong to medium salinity (S2) and low sodium hazards (C3S1), whereas only $12 \%$ samples falls under the high salinity water which considered as unsuitable for soil with restricted drainage. The water quality index of domestic uses was determined and found that $95 \%$ of the spring water samples are under excellent to good category which means that most of the springs are source of fresh drinking water where major chunk of the population in the study area is rely for drinking purposes. The spatial water quality index map shows that most of the study area are fall under excellent to good categories and a few pockets have the poor spatial WQI. The depletion of spring is one of the major problems in the Himalayas due to various socioeconomic and political reasons which has arose the need of spring discharge measurement and in the study it was found that $70 \%$ of the springs dominated by the sandstone lithology have discharge rate of $<20$ Lps whereas the spring in the boulder/sandstone area $17 \%$ springs usually have a discharge rate of 10-20 Lps and required a carefully attention for the revival and rejuvenations of the springs before it comes too late. The overall scenario of the spring water in the study area is chemically potable and suitable for domestic and agricultural uses.

\section{Declaration of competing interest}

The authors declare that they have no known competing financial 


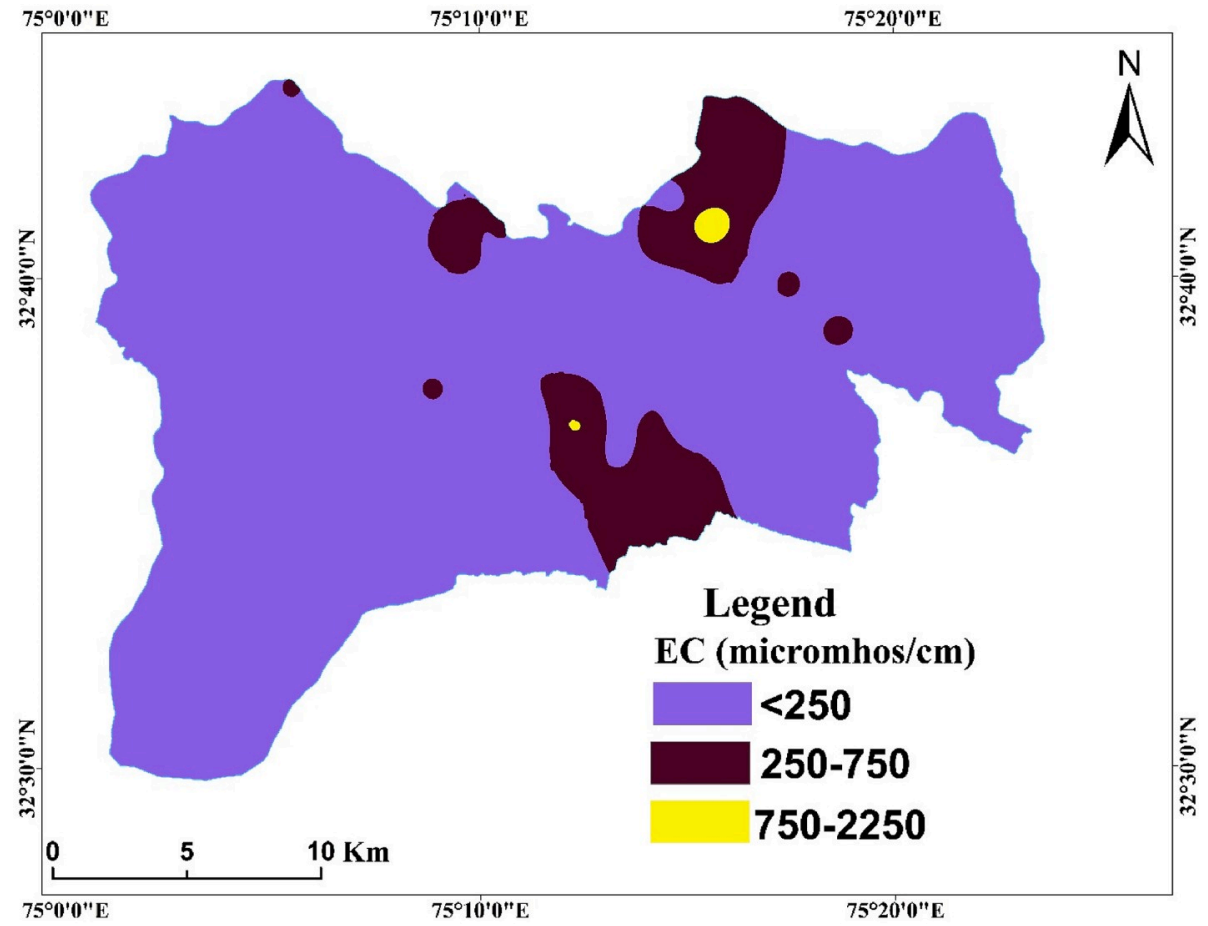

Fig. 8. Spatial distribution of electric conductivity (EC) in the GIS environment.

Table 10

Spring discharge in the study area in different formation.

\begin{tabular}{|c|c|c|c|c|c|}
\hline $\begin{array}{l}\text { Discharge } \\
\text { (LPS) }\end{array}$ & $\begin{array}{l}\text { No. of } \\
\text { Samples }\end{array}$ & $\%$ & $\begin{array}{l}\text { Discharge } \\
\text { point }\end{array}$ & Formation & $\begin{array}{l}\text { Structurally } \\
\text { controlled }\end{array}$ \\
\hline$>20$ & 42 & 70 & $\begin{array}{l}\text { Not at } \\
\text { source }\end{array}$ & Sandstone & Thrust \\
\hline $10-20$ & 10 & 17 & $\begin{array}{l}\text { Not at } \\
\text { source }\end{array}$ & $\begin{array}{l}\text { Boulder } \\
\text { beds/ } \\
\text { Sandstone }\end{array}$ & Fault \\
\hline $2-10$ & 5 & 8 & $\begin{array}{l}\text { Not at } \\
\text { source }\end{array}$ & Alluvium & Lineaments \\
\hline$<2$ & 3 & 5 & $\begin{array}{l}\text { Not at } \\
\text { source }\end{array}$ & $\begin{array}{l}\text { Slit and clay } \\
\text { dominated }\end{array}$ & $\begin{array}{l}\text { Unable to } \\
\text { identify }\end{array}$ \\
\hline
\end{tabular}

interests or personal relationships that could have appeared to influence the work reported in this paper.

\section{Acknowledgements}

The authors are highly thankful to the anonymous reviewers for constant support and thought provoking comments to improve the quality of the manuscript.

\section{Appendix A. Supplementary data}

Supplementary data to this article can be found online at https://doi. org/10.1016/j.gsd.2020.100364.

\section{References}

Aayog, N.I.T.I., 2017. Inventory and Revival of Springs in the Himalayas for Water Security. Department of Science and Technology, Government of India, New Delhi. Adimalla, N., Taloor, A.K., 2020. Hydrogeochemical investigation of groundwater quality in the hard rock terrain of South India using Geographic Information System (GIS) and groundwater quality index (GWQI) techniques. Groundw. Sustain. Develop 10, 100288. https://doi.org/10.1016/j.gsd.2019.100288.

Adimalla, N., Dhakate, R., Kasarla, A., Taloor, A.K., 2020. Appraisal of groundwater quality for drinking and irrigation purposes in Central Telangana, India. Groundw. Sustain. Develop 10, 100334. https://doi.org/10.1016/j.gsd.2020.100334.
Al-Khashman, O.A., Alnawafleh, H.M., Jrai, A.M.A., Ala'a, H., 2017. Monitoring and assessing of spring water quality in southwestern basin of Jordan. Open J. Mod. Hydrol. 7 (4), 331.

Ansari, M.A., Deodhar, A., Kumar, U.S., Khatti, V.S., 2015. Water quality of few springs in outer Himalayas-A study on the groundwater-bedrock interactions and hydrochemical evolution. Groundw. Sustain. Develop. 1 (1-2), 59-67.

APHA, 2012. Standard Methods for the Examination of Water and Wastewater, twentysecond ed. American Public Health Association, Washington, DC.

Barakat, A., Meddah, R., Afdali, M., Touhami, F., 2018. Physicochemical and microbial assessment of spring water quality for drinking supply in Piedmont of Béni-Mellal Atlas (Morocco). Phys. Chem. Earth, Parts A/B/C 104, 39-46.

Bartarya, S.K., 1991. Watershed management strategies in central Himalaya: the Gaula River basin, Kumaun, India. Land Use Pol. 8 (3), 177-184.

Bartarya, S.K., Bahukhandi, D.K., 2012. Impact assessment of urbanization and industrialization on surface and groundwater quality. G. J. Eng. Des. Technol. 1 (1), $11-22$.

Bartarya, S.K., Valdiya, K.S., 1989. Landslides and erosion in the catchment of the Gaula River, Kumaun lesser Himalaya, India. Mt. Res. Dev. 9 (4), 405-419.

Bhat, M.S., Alam, A., Ahmad, B., Kotlia, B.S., Farooq, H., Taloor, A.K., Ahmad, S., 2019. Flood frequency analysis of river Jhelum in Kashmir basin. Quat. Int. 507, 288-294.

BIS, 2012. Indian Standard Specification for Drinking Water (IS 10500: 2012).

Bozau, E., Stärk, H.J., Strauch, G., 2013. Hydrogeochemical characteristics of spring water in the Harz Mountains, Germany. Chemie der Erde-Geochemistry 73 (3), 283-292.

Brindha, K., Elango, L., 2011. Hydrochemical characteristics of groundwater for domestic and irrigation purposes in Madhuranthakam, Tamil Nadu, India. Earth Sci. Res. J. 15 (2), 101-108.

Chen, W., Tsangaratos, P., Ilia, I., Duan, Z., Chen, X., 2019. Groundwater spring potential mapping using population-based evolutionary algorithms and data mining methods. Sci. Total Environ. 684, 31-49.

Davis, S.N., DeWiest, R.J.M., 1966. Hydrogeology. John Wiley \& Sons, New York.

Eaton, F.M., 1950. Significance of carbonates in irrigation waters. Soil Sci. 69 (2), $123-134$.

Fonollosa, E., Peñalver, A., Borrull, F., Aguilar, C., 2016. Radon in spring waters in the south of Catalonia. J. Environ. Radioact. 151, 275-281.

Freeze, R.A., Cherry, J.A., 1979. Groundwater. Prentice-Hall, Englewood Cliffs.

Gibbs, R.J., 1970. Mechanisms controlling world water chemistry. Science 170, 1081-1090.

Guru, B., Seshan, K., Bera, S., 2017. Frequency ratio model for groundwater potential mapping and its sustainable management in cold desert, India. J. King Saud Univ. Sci. 29 (3), 333-347.

Hao, Y., Zhang, J., Wang, J., Li, R., Hao, P., Zhan, H., 2016. How does the anthropogenic activity affect the spring discharge? J. Hydrol. 540, 1053-1065.

Haque, S., Kannaujiya, S., Taloor, A.K., Keshri, D., Bhunia, R.K., Ray, P.K.C., Chauhan, P., 2020. Identification of groundwater resource zone in the active tectonic region of Himalaya through earth observatory techniques. Groundw. Sustain. Develop 10, 100337. https://doi.org/10.1016/j.gsd.2020.100337.

Horton, R.K., 1965. An index number system for rating water quality. J. Water Pollut. Control Fed. 37 (3), 300-306. 
Jasik, M., Małek, S., Żelazny, M., 2017. Effect of water stage and tree stand composition on spatiotemporal differentiation of spring water chemistry draining Carpathian flysch slopes (GorceMts). Sci. Total Environ. 599, 1630-1637.

Jasrotia, A.S., Kumar, A., 2014a. Groundwater quality mapping based on the geographical information system (GIS) of Jammu district, Jammu and Kashmir India. J. Spatial Hydrol. 12 (1), 1-21.

Jasrotia, A.S., Kumar, A., 2014b. Estimation of replenishable groundwater resources and their status of utilization in Jammu Himalaya, J\&K, India. Eur. Water 48, 17-27.

Jasrotia, A.S., Kumar, A., Aasim, M., 2011. Morphometric analysis and hydrogeomorphology for delineating groundwater potential zones of Western Doon Valley, Uttarakhand, India. Int. J. Geomatics Geosci. 2 (4), 1078-1096.

Jasrotia, A.S., Taloor, A.K., Andotra, U., Bhagat, B.D., 2018. Geoinformatics based groundwater quality assessment for domestic and irrigation uses of the Western Doon valley, Uttarakhand, India. Groundw. Sustain. Develop. 6, 200-212.

Jasrotia, A.S., Kumar, A., Taloor, A.K., Saraf, A.K., 2019a. Artificial recharge to groundwater using geospatial and groundwater modelling techniques in North Western Himalaya, India. Arab J. Geosci. 12, 774. https://doi.org/10.1007/s12517019-4855-5.

Jasrotia, A.S., Taloor, A.K., Andotra, U., Kumar, R., 2019b. Monitoring and assessment of groundwater quality and its suitability for domestic and agricultural use in the Cenozoic rocks of Jammu Himalaya, India: a geospatial technology based approach. Groundw. Sustain. Develop. 8, 554-566.

Joshi, B.K., 2006. Hydrology and nutrient dynamics of spring of Almora-Binsar area, Indian Central Himalaya: landscapes, practices, and management. Water Resour. 33 (1), 87-96.

Karanth, K.R., 1987. Ground Water Assessment: Development and Management. Tata McGraw- Hill Education.

Negi, G.C., Joshi, V., 2004. Rainfall and spring discharge patterns in two small drainage catchments in the Western Himalayan Mountains, India. Environmentalist 24 (1), 19-28.

Nnorom, I.C., Ewuzie, U., Eze, S.O., 2019. Multivariate statistical approach and water quality assessment of natural springs and other drinking water sources in Southeastern Nigeria. Heliyon 5 (1), e01123. https://doi.org/10.1016/j. heliyon. 2019.

Ozdemir, A., 2011. GIS-based groundwater spring potential mapping in the Sultan Mountains (Konya, Turkey) using frequency ratio, weights of evidence and logistic regression methods and their comparison. J. Hydrol. 411 (3-4), 290-308.

Piper, A.M., 1953. A Graphic Procedure in the Geo-Chemical Interpretation of Water Analysis. USGS Groundwater note no. 12.
Pourtaghi, Z.S., Pourghasemi, H.R., 2014. GIS-based groundwater spring potential assessment and mapping in the Birjand Township, southern Khorasan Province, Iran. Hydrogeol. J. 22 (3), 643-662.

Raghunath, H.M., 1987. Groundwater. Wiley Eastern Ltd, Delhi, India.

Rahmati, O., Naghibi, S.A., Shahabi, H., Bui, D.T., Pradhan, B., Azareh, A., RafieiSardooi, E., Samani, A.N., Melesse, A.M., 2018. Groundwater spring potential modelling: comprising the capability and robustness of three different modeling approaches. J. Hydrol. 565, 248-261.

Ramakrishnaiah, C.R., Sadashivaiah, C., Ranganna, G., 2009. Assessment of water quality index for the groundwater in Tumkur Taluk, Karnataka State, India. J. Chem. 6 (2), 523-530. https://doi.org/10.1155/2009/757424.

Ranga Rao, A., Agarwal, R.P., Sharma, U.N, Bhalla, M.S., Nanda, A.C, 1988. Magnetic polarity stratigraphy and vertebrate paleontology of the Upper Siwalik Sub-group of Jammu hills, India.. In: , 31. Journal of the Geolgoical Society of India 31, pp. 361-385.

Reyes, F.A.P., Crosta, G.B., Frattini, P., Basiricò, S., Della Pergola, R., 2015. Hydrogeochemical overview and natural arsenic occurrence in groundwater from alpine springs (upper Valtellina, Northern Italy). J. Hydrol. 529, 1530-1549.

Richards, L.A., 1954. Diagnosis and Improvement of Saline and Alkali Soils, vol. 60. U. S. Department of Agriculture Handbook, Washington USA, p. 160.

Saha, R., Dey, N.C., Rahman, S., Galagedara, L., Bhattacharya, P., 2018. Exploring suitable sites for installing safe drinking water wells in coastal Bangladesh. Groundw. Sustain. Develop. 7, 91-100.

Sawyer, C.N., McCarty, P.L., 1967b. Chemistry for Sanitary Engineers. McGraw-Hill, NewYork.

Singh, A.K., Jasrotia, A.S., Taloor, A.K., Kotlia, B.S., Kumar, V., Roy, S., Ray, P.K.C., Singh, K.K., Singh, A.K., Sharma, A.K., 2017. Estimation of quantitative measures of total water storage variation from GRACE and GLDAS-NOAH satellites using geospatial technology. Quat. Int. 444, 191-200.

USSL, 1954. Diagnosis and improvement of saline and alkali soils. Agric. Hand b. 60, 160.

Varol, S., Davraz, A., 2015. Evaluation of the groundwater quality with WQI (Water Quality Index) and multivariate analysis: a case study of the Tefenni plain (Burdur/ Turkey). Environ. Earth Sci. 73 (4), 1725-1744.

WHO, 1984. Guidelines for Drinking Water Quality. World Health Organization, Geneva. Wilcox, L.V., 1955. Classification and Use of Irrigation Water. US Department of Agriculture, Washington, p. 19. Circular No. 969. 